\title{
FREQUENCY OF ANTIBODIES AGAINST Neospora caninum IN STRAY AND DOMICILED DOGS FROM URBAN, PERIURBAN AND RURAL AREAS FROM PARANÁ STATE, SOUTHERN BRAZIL*
}

\author{
NICOLLE FRIDLUND-PLUGGE ${ }^{1}$; FABIANO MONTIANI-FERREIRA²; ROSÁRIA R.T.B. RICHARTZ ${ }^{3}$; \\ JULIANO DAL PIZZOL ${ }^{4}$; PEDRO C. MACHADO JR ${ }^{4}$; LIA F.L. PATRÍCIO ${ }^{4}$; ADRIANA S. ROSINELLI ${ }^{5}$; \\ ROSANGELA LOCATELLI-DITTRICH ${ }^{2}$
}

\begin{abstract}
FRIDLUND-PLUGGE, N.; MONTIANI-FERREIRA, F.; RICHARTZ, R. R.T.B.; DAL PIZZOL, J.; MACHADO JR, P.C.; PATRÍCIO, L.F.L.; ROSINELLI, A.S.; LOCATELLI-DITTRICH, R. Frequency of antibodies against Neospora caninum in stray and domiciled dogs from urban, periurban and rural areas from Paraná state, Southern Brazil. [Frequência de anticorpos contra Neospora caninum em cães errantes e domiciliados das áreas urbana, periurbana e rurais do Estado do Paraná, sul do Brasil]. Revista Brasileira de Parasitologia Veterinária, v. 17, n. 4, p.222-226, 2008. Departamento de Medicina Veterinária, Universidade Federal do Paraná, Rua dos Funcionários, 1540, Curitiba, PR 80035-050, Brazil. E-mail: roslocdi@ufpr.br

Antibodies to Neospora caninum were analyzed by an indirect fluorescent antibody test (IFAT), in stray and domiciled dogs from urban, periurban and rural areas from Curitiba, Paraná State, Brazil. Of the total of 556 dogs, $18.17 \%$ (101) were positive for $N$. caninum (titer 50). Frequency of antibody was 12.71 in urban, 15.73 in periurban, and $25.38 \%$ in rural dogs. Rural dogs had a significantly higher frequency of antibodies than urban dogs $(P<0.05)$. There were no significant differences between the frequencies of antibodies in urban and periurban $\operatorname{dogs}(P>0.05)$, and between dogs from periurban and rural areas $(P>0.05)$. Antibodies to $N$. caninum were detected in 34 of 233 domiciled dogs (14.59\%) and in 17 of 126 stray dogs (13.49\%). No statistical differences were observed considering life-style and geographic location of origin $(P>0.05)$. Neospora caninum is widespread among dogs from urban, periurban and rural areas of the municipal district of Curitiba, Paraná, Brazil.
\end{abstract}

KEY WORDS: Neosporosis; antibodies; indirect fluorescent antibody test.

\section{RESUMO}

Anticorpos anti-Neospora caninum foram detectados pela reação de imunofluorescência indireta (RIFI), em cães errantes e domiciliados das áreas urbana, periurbana e rurais de Curitiba, estado do Paraná, Brasil. Do total de 556 cães, 18,17\% (101) foram soropositivos para $N$. caninum (título de 1:50). A frequência de anticorpos foi de $12,71 \%$ nos cães urbanos, de $15,73 \%$ nos periurbanos e de $25,38 \%$ nos cães ru-

\footnotetext{
*Supported by CNPq, UFPR and Fundação Araucaria/PR.

${ }^{1}$ Programa de Pós-Graduação em Ciências Veterinárias, Universidade Federal do Paraná (UFPR), Rua dos Funcionários, 1540, Curitiba, PR 80035050, Brazil.

${ }^{2}$ Departamento de Medicina Veterinária, UFPR, Rua dos Funcionários, 1540, Curitiba, PR 80035-050, Brazil. E-mail: roslocdi@ufpr.br

${ }^{3}$ Centro de Diagnóstico Marcos Enrietti (SEAB/PR), Rua dos Funcionários, 1540, Curitiba, PR.

${ }^{4}$ Médicos-Veterinários, Curitiba, PR, Brazil.

${ }^{5}$ Bolsista de Iniciação Científica - CNPq, UFPR.
}

rais. Nos cães rurais a frequência de anticorpos foi maior do que nos cães urbanos $(P<0.05)$. Não houve diferença significativa entre as frequências de anticorpos dos cães urbanos e periurbanos $(P>0,05)$, e dos periurbanos e rurais $(P>0,05)$. Os anticorpos anti $N$. caninum foram detectados em 34 de 233 cães domiciliados (14,59\%) e em 17 de 126 cães errantes $(13,49 \%)$. Não houve diferença estatística significativa entre o tipo de criação e a origem $(P>0,05)$. Neospora caninum está presente nos cães urbanos e periurbanos de Curitiba e nas áreas rurais do Estado do Paraná.

PALAVRAS-CHAVE: Neosporose; anticorpos; reação de imunofluorescência indireta.

\section{INTRODUCTION}

Neospora caninum is an apicomplexan protozoan that was first described and isolated from dogs (DUBEY et al., 1988) and later associated with bovine abortion. The parasite has since been recognized as one of the major causes of abortion 
in cattle worldwide as well as a causative agent of neuromuscular disease in dogs (McINNES et al., 2006). Besides being a possible cause of neuromuscular disease, the protozoan might also produce myocardial, pulmonary and dermal diseases in dogs (McINNES et al., 2006). Domestic dogs and coyotes are considered the definitive hosts for $N$. caninum (Mc ALLISTER et al., 1998; GONDIM et al., 2004).

Antibodies to $N$. caninum in canine populations were reported in several countries, and the seroprevalence has been reported from 4 to 54.2\% (DUBEY, 2003). In South America, antibodies to $N$. caninum were detected in dogs from Uruguay (BARBER et al., 1997), Argentina (BASSO et al., 2001), Chile (PATITUCCI et al., 2001) and Brazil (CAÑON-FRANCO et al. 2003; FERNANDES et al., 2004; GUIMARÃES Jr. et al., 2004; ROMANELLI et al., 2007).

There are few studies comparing isolated characteristics of the animals such as seroprevalence of $N$ caninum in stray dogs versus domiciled dogs. The presence of $N$. caninum antibodies in urban dogs of the city of Curitiba, Parana state, and in periurban dogs from the city's metropolitan area is not known yet. In this context, the objectives of this study were: (1) to determine the frequency of antibodies against Neospora caninum in domiciled and stray dogs from urban and periurban areas of the city of Curitiba, Paraná (PR), Brazil, and in domiciled dogs from rural areas of Paraná state; (2) to perform multiple comparisons of the proportion of frequencies of antibodies obtained in domiciled and stray dogs living in all geographic locations, urban versus periurban versus rural areas.

\section{MATERIALS AND METHODS}

Study area and sampling. Between March 2006 and March 2007, 556 domestic dogs of different breeds, sex, ages and without neurological signs, were included in the study. These animals came from the urban (181 dogs) and periurban (178) areas of Curitiba and from rural areas (197 dogs) of Paraná state, Southern Brazil. The blood samples from urban and periurban animals were obtained from dogs presented to the Veterinary Teaching Hospital of the Universidade Federal do Paraná and to private veterinary clinics of the City of Curitiba. The samples from periurban dogs came from: Zoonosis Control Centers, located at the Cities of Pinhais and São José dos Pinhais; from the Non-Governmental Organization "Amigo Animal”, at the City of Campo Magro, and from the Military Police Prison located in the City of Piraquara. Information regarding the life-style (stray or domiciled) and the origin (urban and periurban) of the dogs was also obtained. Of the 359 animals from urban and periurban areas, 233 were domiciled and 126 were stray dogs. From the 233 domiciled, 165 lived in Curitiba and 68 dogs lived in the metropolitan area of Curitiba (Pinhais, São José dos Pinhais, Campo Magro, and Piraquara). From the 126 stray dogs, 16 lived in the City and 110 lived in the metropolitan area of Curitiba. The rural dogs belonged to dairy farms in the east of the State of Paraná in the Municipalities of Castro and Colônia Wittmarsum.
Blood collection. The blood samples were collected by cephalic or jugular vein punctures and centrifuged at $700 \mathrm{x} \mathrm{g}$ for $10 \mathrm{~min}$. Sera were separated and stored at $-20^{\circ} \mathrm{C}$ until serological testing.

Serology for $N$. caninum. An indirect fluorescent antibody test (IFAT) was used for detection of anti- $N$. caninum antibodies, as previously described (DUBEY et al., 1988). Antigen of $N$. caninum culture-derived tachyzoites of the NC1 isolate was produced and prepared according to LocatelliDittrich et al. (2006). Reactions in which tachyzoites presented total peripheral fluorescence were deemed positive, using the cut-off dilution of 1:50 (ROMANELLI et al., 2007). All seropositive sera were retested using two-fold serial dilutions. Positive and negative control sera were included in each slide.

Statistical analysis. The data were analyzed using Chisquare tests to determine differences in frequencies of antibodies between groups $(P \leq 0.05)$.

\section{RESULTS}

Of a total of 556 dogs tested, $18.17 \%$ (101) were seropositive for anti- $N$. caninum at titers of 50 , in which $12.71 \%(23 / 181)$ came from the urban area, $15.73 \%(28 / 178)$ from the periurban area, and 25.38\% (50/197) from the rural area (Table 1). Statistical differences were observed between the frequency in dogs from urban areas and those from rural areas $(P \leq 0.02)$. Statistical differences were not observed between the frequency in dogs from urban areas and those from periurban areas $(P \leq 1)$ and between dogs from periurban and rural areas $(P \leq 0.10)$.

Considering the dog's exposure to the rural environment as a potential risk factor, the prevalence ratio between rural and urban dogs was calculated, resulting in a moderately high positive association $(\operatorname{Pr}=2.0)$, showing that rural dogs might be considered at a higher risk of developing $N$. caninum seropositivity.

Of the 233 domiciled dogs, antibodies to $N$. caninum were found in $13.33 \%(22 / 165)$ and $17.65 \%(12 / 68)$ with titer of 50 , respectively, for urban and periurban areas. Of the 126 stray dogs, $6.25 \%(1 / 16)$ and $14.55 \%(16 / 110)$ had titers of 50 , respectively, for urban and periurban areas. No statistical differences were observed between the life-style and geographic location of origin $(P \leq 1)$ (Table 2$)$.

Table 1. Frequency of antibodies against Neospora.caninum in sera of dogs from urban and periurban areas in the municipality of Curitiba and from rural areas in the state of Paraná, southern Brazil.

\begin{tabular}{cccc}
\hline \multirow{2}{*}{ Areas } & \multicolumn{3}{c}{ Samples } \\
\cline { 2 - 4 } & Examined & Positive* $^{*}$ & $\%$ \\
\hline Urban & 181 & 23 & $12.71 \mathrm{a}$ \\
Periurban & 178 & 28 & $15.73 \mathrm{ab}$ \\
Rural & 197 & 50 & $25.38 \mathrm{~b}$ \\
Total & 556 & 101 & 18.17 \\
\hline
\end{tabular}

Different letters in the column: $P \leq 0.05 .{ }^{*}$ IFAT $\geq 50$ 
Table 2. Frequencies of anti-Neospora caninum antibodies in domiciled and stray dogs from urban and periurban areas of Curitiba, the state of Paraná, Brazil.

\begin{tabular}{lccc}
\hline Life-style & $\mathrm{N}^{\circ}$ of dogs & $\mathrm{N}^{\circ}$ of positives* $(\%)$ \\
\hline Domiciled & & & \\
$\quad$ Urban & 165 & 22 & $(13.33)$ \\
Periurban & 68 & 12 & $(17.65)$ \\
Total & 233 & 34 & $(14.59)$ \\
Stray & & & \\
$\quad$ Urban & 16 & 1 & $(6.25)$ \\
Periurban & 110 & 16 & $(14.55)$ \\
Total & 126 & 17 & $(13.49)$ \\
\hline
\end{tabular}

* IFAT $\geq 50$

\section{DISCUSSION}

The results of this study indicate that dogs from urban, periurban, and rural areas in Paraná state, Brazil are exposed to Neospora caninum and, curiously, domiciled and stray dogs have similar seroprevalences. The presence of anti-N.caninum antibodies in urban (12.71\%), periurban (15.73\%) and rural dogs (25.38\%) detected in this study corroborates the results of Fernandes et al. (2004), who observed a prevalence of $10.70 \%$ in urban dogs, $18.9 \%$ in periurban dogs and $21.7 \%$ in rural dogs from Minas Gerais state, Brazil. Few studies compared the seroprevalence between stray and domiciled dogs (GENNARI et al., 2002; AZEVEDO et al. 2005; JESUS et al., 2006) and only one investigation compared the seroprevalence in urban, periurban and rural dogs (FERNANDES et al., 2004).

In the present study, the highest frequencies were detected in periurban and rural dogs, however, without statistical differences between these populations examined. The higher trend of seroprevalence found in periurban dogs, when compared to dogs from urban areas, may be explained by the fact that those animals live close to small rural farms, in the presence of potential intermediate hosts, hunting possibilities and feeding habits that include homemade diet, contrary to the major part of the urban dogs, which are usually fed with commercial dog food and seldom get in contact with intermediate hosts. Fernandes et al. (2004) reported $N$. caninum antibodies in $10.70 \%$ of 300 dogs from urban area and $18.9 \%$ of 58 dogs from periurban areas in Brazil, also suggesting that in periurban environment there are potential intermediary hosts that facilitate the contact of the animals with the agent.

The frequency found for anti-N. caninum antibodies in rural dogs (25.38\%) was similar to the $21.6 \%$ found by Souza et al. (2002) in dogs of the rural area of the northern region of the state of Paraná and to Romanelli et al. (2007) who observed, in Guarapuava, Paraná state, similar seroprevalence (29.1\%) in dogs also in the rural area. In the present study significant differences were observed between the seroprevalence in dogs from urban versus rural areas. The highest seroprevalence in rural dogs compared with urban dogs (25.38\% versus $12.71 \%$ ) may be explained by the fact that in the rural environment, dogs may acquire infection by ingesting cattle tissues, especially placentas and aborted fetuses of infected bovine (DIJKSTRA et al.; 2002). In Paraná state, N. caninum was isolated from a bovine fetus and from a blind calf, confirming the presence of the parasite in cattle from this area (LOCATELLI-DITTRICH et al., 2003; LOCATELLIDITTRICH et al., 2004). wWestern Amazon, northern Brazil, Aguiar et al. (2006) noted the occurrence of anti-N. caninum antibodies in $12.6 \%$, a lower seroprevalence than that observed in his study. Sawada et al. (1998) in Japan, Wouda et al. (1999) in Holland, and Basso et al. (2001) in Argentina, also reported higher seroprevalence in dogs from the rural area in comparison to those of the urban areas.

The seroprevalence of $N$. caninum in $12.71 \%$ of urban dogs was similar to the $12 \%$ of 120 urban dogs from Chile (PATITUCCI et al., 2001). Fernandes et al. (2004) reported $N$. caninum antibodies in $10.7 \%$ of 300 urban dogs. However, Teixeira et al. (2006) in São Luís, Maranhão, Brazil, observed a very high seroprevalence (31.1\%) in urban dogs from Zoonosis Control Centers. In urban dogs of the municipalities of Monte Negro, Rondônia, and Campina Grande, Paraíba, Brazil, Cañon-Franco et al. (2003) and Azevedo et al. (2005), respectively, reported seroprevalences of $8.3 \%$ and $8.4 \%$, lower results than that observed in this study.

There are few reports in the literature comparing the prevalence of anti- $N$. caninum antibodies in domiciled and stray dogs (GENNARI et al., 2002; AZEVEDO et al., 2005; JESUS et al., 2006). No statistical differences were observed between all possible comparisons of urban, periurban, domiciled and stray dogs, neither between the stray dogs and domiciled dogs in both origins $(P \leq 1)$, suggesting that dogs having greater access to streets, in the city of Curitiba and metropolitan areas, did not positively influence the seroprevalence results. Similar results were found by Jesus et al. (2006), that reported $N$. caninum antibodies in $11.2 \%$ of the stray dogs and $13.3 \%$ of the domiciled dogs from Bahia state, Brazil, and no statistical differences were observed between the two geographic locations. However, Gennari et al. (2002) reported a higher seroprevalence in stray dogs (25\% of 611) versus domiciled dogs (10\% of 500) from urban area in São Paulo (SP), Brazil, using the agglutination test as the diagnostic method. Azevedo et al. (2005) observed correlation between canine seroprevalence for $N$. caninum and access to street, in Paraíba State, Brazil. The different seroprevalences detected in dogs were probably because of differences in the diet consumed by the canine population examined.

The results of this study show that subclinical infection with $N$. caninum is widespread among dogs from urban, periurban and rural areas of the municipal district of Curitiba, Paraná and reinforce the importance of the fact that dogs carry the protozoan in those environments. Although no statistical differences were observed between the occurrences in stray and domiciled dogs from the urban and periurban areas, it should be considered the small size of the analyzed sample, mainly of stray dogs from Curitiba. More studies associating risk factors for canine neosporosis in periurban areas must be 
performed. Additionally, further studies are required in dogs living in rural areas to verify their real participation in the epidemiology of the disease.

Acknowledgements:- The authors would like to thank the veterinary clinics of the Veterinary Teaching Hospital of the Universidade Federal do Paraná (UFPR), the Zoonosis Control Centers from Pinhais and São José dos Pinhais, and the NonGovernmental Organization "Amigo Animal”. The authors are also very grateful to the owners of the dogs for their help and co-operation.

\section{REFERENCES}

AGUIAR, D.M.; CAVALCANTE, G.T.; RODRIGUES, A.A.R.; LABRUNA, M.B.; CAMARGO, L.M.A.; CAMARGO, E.P.; GENNARI, S.M. Prevalence of anti-Neospora caninum antibodies in cattle and dogs from Western Amazon, Brazil, in association with some possible risk factors. Veterinary Parasitology, v. 142, n. 1-2, p. 71-77, 2006.

AZEVEDO, S.S.; BATISTA, C.S.; VASCONCELLOS, S.A.; AGUIAR, D.M.; RAGOZO, A.M.; RODRIGUES, A.A.; ALVES, C.J.; GENNARI, S.M. Seroepidemiology of Toxoplasma gondii and Neospora caninum in dogs from the state of Paraiba, Northeast region of Brazil. Research in Veterinary Science, v.79, n. 1, p. 51-56, 2005.

BARBER, J.S.; GASSER, R.B.; ELLIS, J.; REICHEL, M.P.; MCMILLAN, D.; TRESS, A.J. Prevalence of antibodies to Neospora caninum in different canid populations. Journal of Parasitology, v. 83, n. 6, p. 1056-1058, 1997.

BASSO, W.; VENTURINI, L.; VENTURINI, M.C.; MOORE, D.P.; RAMBEAU, M.; UNZAGA, J.M.; CAMPERO, C.; BACIGALUPE, D.; DUBEY, J.P. Prevalence of Neospora caninum infection in dogs from beef cattle farms, dairy farms, and from urban areas of Argentina. Journal of Parasitology, v. 87, n. 3, p. 906-907, 2001.

CAÑÓN-FRANCO, W.A.; BERGAMASCHI, D.P.; LABRUNA, M.B.; CAMARGO, L.M.A.; SOUZA, S.L.P.; SILVA, J.C.R.; PINTER, A.; DUBEY, J.P.; GENNARI, S.M. Prevalence of antibodies anti-Neospora caninum in dogs from Amazon, Brazil. Veterinary Parasitology, v. 115, n. 1, p. 71-74, 2003.

DIJKSTRA, T.; BARKEMA, H.W.; EYSKER, M.; HESSELINK, J.W.; WOUDA, W. Natural transmission routes of Neospora caninum between farm dogs and cattle. Veterinary Parasitolgy, v. 105, n. 2, p. 99-104, 2002.

DUBEY, J.P.; HATTEL, A.L.; LINDSAY, D.S.; TOPPER, M.J. Neonatal Neospora caninum infection in dogs: isolation of the causative agent and experimental transmission. Journal of American Veterinary Medical Association, v. 193, n. 10, p. 1259-1263, 1988.

DUBEY, J.P. Review of Neospora caninum and neosporosis in animals. Korean Journal of Parasitology, v. 41, n. 1, p. 1-16, 2003.

FERNANDES, B.C.T.M.; GENNARI, S.M.; SOUZA, S.L.P.;
CARVALHO, J.M.; OLIVEIRA, W.G.; CURY, M.C. Prevalence of anti-Neospora caninum antibodies in dogs from urban, periurban and rural areas of the city of Uberlândia, Minas Gerais, Brazil. Veterinary Parasitology, v. 123, n. 1-2, p. 33-40, 2004.

GENNARI, S.M.; YAI, L.E.; D'AURIA, S.N.R.; CARDOSO, S.M.S.; KWOK, O.C.H.; JENKINS, M.C.; DUBEY, J.P. Occurrence of Neospora caninum antibodies in sera from dogs of the city of São Paulo, Brazil. Veterinary Parasitology, v. 106, n. 2, p. 177-179, 2002.

GONDIM, L.F.P.; MCALLISTER, M.M.; PITT, W.C.; ZEMLICKA, D.E. Coyotes (Canis latrans) are definitive hosts of Neospora caninum. International Journal of Parasitology, v. 34, n. 2, p. 159-161, 2004.

GUIMARÃES JUNIOR, J.S.; SOUZA, S.L.P.; BERGAMASHI, D.P.; GENNARI, S.M. Prevalence of Neospora caninum antibodies and factors associated with their presence in dairy cattle of the north of Paraná state, Brazil. Veterinary Parasitology, v. 124, n. 1-2, p. 1-8, 2004.

JESUS, E.E.V.; SANTOS, P.O.M.; BARBOSA, M.V.F.; PINHEIRO, A.M.; GONDIM, L.F.P.; GUIMARÃES, J.E.; ALMEIDA, M.A.O. Freqüência de anticorpos anti-Neospora caninum em cães nos municípios de Salvador e Lauro de Freitas, Estado da Bahia - Brasil. Brazilian Journal of Veterinary Research and Animal Science, v. 43, n. 1, p. 5-10, 2006.

LOCATELLI-DITTRICH, R.; RICHARTZ, R.R.T.B.; GASINO-JOINEAU, M.E.; PINCKNEY, R.D.; SOUSA, R.S.; LEITE, L.C.; THOMAZ-SOCCOL, V. Isolation of Neospora caninum from a blind calf in Paraná, southern Brazil. Veterinary Record, v. 153, n. 12, p. 366-367, 2003.

LOCATELLI-DITTRICH, R.; THOMAZ-SOCCOL, V.; RICHARTZ, R.R.T.B.; GASINO-JOINEAU, M.E.; VAN DER VINNE, R.; PINCKNEY, R.D. Isolamento de Neospora caninum de feto bovino de rebanho leiteiro no Paraná. Revista Brasileira de Parasitologia Veterinária, v. 13, n. 3, p. 103-109, 2004.

LOCATELLI-DITTRICH, R.; DITTRICH, J.R.; RICHARTZ, R.R.T.B.; GASINO-JOINEAU, M.E.; ANTUNES, J.; PINCKNEY, R.D.; DECONTO, I.; HOFFMANN, D.C.S.; THOMAZ-SOCCOL, V. Investigation of Neospora sp. and Toxoplasma gondii antibodies in mares and in precolostral foals from Parana State, Southern Brazil. Veterinary Parasitology, v. 135, n. 3-4, p. 215-221, 2006.

MCALLISTER, M.M.; DUBEY, J.P.; LINDSAY, D.S.; JOLLEY, W.R.; WILLS, R.A.; MCGUIRE, A.M. Dogs are definitive hosts of Neospora caninum. International Journal of Parasitology, v. 28, n. 9, p. 1473-1478, 1998.

MCINNES, L.M.; IRWIN, P.; PALMER, D.G.; RYAN, U.M. In vitro isolation and characterization of the first canine Neospora caninum isolate in Australia. Veterinary Parasitology, v. 137, n. 3-4, p. 355-363, 2006.

PATITUCCI, A.N.; PÉREZ, M.J.; ROZAS, M.A.; ISRAEL, K.F. Neosporosis canine: detection of sera antibodies in rural and urban canine population of Chile. Archives of Medicine Veterinary, v. 33, n. 2, p. 227-232, 2001. 
ROMANELLI, P.R.; FREIRE, R.L.; VIDOTTO, O.; MARANA, E.R.M.; OGAWA, L.; DEPAULA, V.S.O.; GARCIA, J.L.; NAVARRO, I.T. Prevalence of Neospora caninum and Toxoplasma gondii in sheep and dogs from Guarapuava farms, Paraná State, Brazil. Research in Veterinary Science, v. 82, n. 2, p. 202-207, 2007.

SAWADA, M., PARK, C. H., KONDO, H.; MORITA, T.; SHIMADA, A.; YAMANE, I.; UMEMURA, T. Serological survey of antibody to Neospora caninum in Japanese dogs. Journal of Veterinary Medical Science, v. 60, n. 7, p. 853854, 1998.

SOUZA, S.L.P.; GUIMARÃES JR., J.S.; FERREIRA, F.; DUBEY, J.P.; GENNARI, S.M. Prevalence of Neospora caninum antibodies in dogs from dairy cattle farms in $\mathrm{Pa}-$ raná, Brazil. Journal of Parasitology, v. 88, n. 2, p. 408409, 2002.

TEIXEIRA, W.C.; SILVA, M.I.S.; PEREIRA, J.G.; PINHEIRO, A.M.;ALMEIDA, M.A.O.; GONDIM, L.F.P. Freqüência de cães reagentes para Neospora caninum em São Luís, Maranhão. Arquivo Brasileiro de Medicina Veterinária e Zootecnia, v. 58, n. 4, p. 685-687, 2006.

WOUDA, W.; DIJKSTRA, T.; KRAMER, A.M.H.; VAN MANEN, C.; BRINKHOF, J.M.A. Seroepidemiological evidence for a relationship between Neospora caninum infections in dogs and cattle. International Journal of Parasitology, v. 29, n. 10, p. 1677-1682, 1999.

Received on November 21, 2007.

Accepted for publication on November 10, 2008. 